\title{
Preliminary investigation of the pharmacology of the human internal anal sphincter
}

\author{
A. G. PARKS, D. J. FISHLOCK, J. D. H. CAMERON, AND H. MAY ${ }^{1}$ \\ From the Research Department, St Mark's Hospital, London
}

SUMMARY The smooth muscle from the human internal anal sphincter has been investigated pharmacologically in vitro. The upper and lower parts of the sphincter responded to catecholamines in a similar manner. Noradrenaline caused contraction which could be antagonized by phenoxybenzamine. After phenoxybenzamine, noradrenaline caused relaxation which could be blocked by pronethalol. Isoprenaline caused relaxation which could be specifically prevented by pronethalol. Adrenaline was variable in its effect: low concentrations caused relaxation and high concentrations caused contraction. It is suggested that the anal smooth muscle contains $\alpha$-adrenergic receptors subserving contraction and $\beta$-receptors subserving relaxation.

The lower part of the sphincter was generally insensitive to acetylcholine and nicotine whereas the upper part of the sphincter contracted with acetylcholine and regularly relaxed with nicotine. The nicotine response was antagonized by hexamethonium, procaine, and pronethalol. It is suggested that nicotine stimulated some part of the nervous mechanism in the upper part of the sphincter and that a catecholamine was the mediator of the inhibitory response.

The internal sphincter of the human anus forms the inner muscle layer of the whole anal canal and is a thickened continuation of the smooth muscle of the circular layer of the rectum. The activity of the sphincter is presumably under the influence of the autonomic nervous system, but very little is known about this. This paper describes the behaviour of muscle strips obtained from the upper and lower parts of the sphincter in response to noradrenaline, adrenaline, isoprenaline, acetylcholine, and nicotine.

\section{METHOD}

Strips 20 to $30 \mathrm{~mm}$ long, 1 to $2 \mathrm{~mm}$ wide, and about $2 \mathrm{~mm}$ thick were taken from either the proximal or the distal part of the human internal anal sphincter, usually from specimens obtained at abdomino-perineal excision. Each strip consisted only of the circular muscle of the sphincter with any nervous tissue that it might contain. The strips were immediately placed in a modified Krebs' solution equilibrated with $95 \% \mathrm{O}_{2}$ and $5 \% \mathrm{CO}_{2}$, at a temperature of $37^{\circ} \mathrm{C}$. A description of the saline solution used and details of the method have been reported previously (Fishlock and Parks, 1966), the only difference being that the recording was made by means of an isotonic lever with an ink fountain attachment. By trial and error it was found that the preparation required a tension of $2.5 \pm 1.5 \mathrm{~g}$ to maintain a steady base-line.

'Present address of Dr H. May: München 27, Wehrlestr 28 (Herkomerplatz), Germany
The following drugs were used: acetylcholine chloride, adrenaline acid tartrate, hexamethonium bromide, isoprenaline sulphate, nicotine hydrogen tartrate, 1-noradrenaline bi-tartrate, phenoxybenzamine (Dibenzyline, Smith Kline, and French), procaine hydrochloride, and pronethalol hydrochloride.

Concentrations refer to the salts. All solutions were made with physiological saline $(0.9 \% \mathrm{NaCl})$ except for the solutions of adrenaline, isoprenaline, and noradrenaline which were made with acidified $(\mathrm{HCl})$ physiological saline ( $p \mathrm{H} 4 \cdot 5)$.

\section{RESULTS}

The investigation involved 102 strips of the lower part of the internal anal sphincter from 87 patients and 34 strips of the upper part from 26 patients. Most of the preparations were subjected to two or more drugs so that the number of observations recorded is in excess of the number of strips used. The antagonists pronethalol, phenoxybenzamine, and procaine sometimes reduced the base-line of the preparation but hexamethonium did not affect it.

CATEChOlamines The response of both the upper and lower parts of the sphincter are shown in Table I. The response to noradrenaline was nearly always a contraction. This was antagonized by phenoxybenzamine, the lowest effective concentration being 
TABLE I

\begin{tabular}{|c|c|c|c|c|}
\hline \multicolumn{5}{|c|}{ RESPONSE OF THE SPHINCTER TO CATECHOLAMINES } \\
\hline Region of Sphincter & Catecholamine & No. of Experiments & Response & $\begin{array}{l}\text { Concentration Range } \\
(\mu \mathrm{g} / \mathrm{ml})\end{array}$ \\
\hline & $\begin{array}{l}\text { Isoprenaline } \\
\text { Adrenaline }\end{array}$ & $\begin{array}{l}15 \\
18\end{array}$ & $\begin{array}{l}\text { Relaxation (15) } \\
\text { Contraction (10) } \\
\text { Relaxation (8) }\end{array}$ & $\begin{array}{l}0.01-10 \cdot 0 \\
1 \cdot 0-10 \cdot 0 \\
0 \cdot 01-0 \cdot 1\end{array}$ \\
\hline
\end{tabular}

$7.5 \pm 2.5 \mu \mathrm{g} / \mathrm{ml}$ (10-min exposure). Following blockade of the contraction a relaxation was unmasked which was antagonized by pronethalol ( $2.5 \mu \mathrm{g} / \mathrm{ml}, 5 \mathrm{~min})$.

The response to isoprenaline was always a relaxation. The minimum effective concentration of pronethalol which antagonized this response was $2.5 \mu \mathrm{g} / \mathrm{ml}$ ( $5 \mathrm{~min}$ exposure). This did not unmask a contraction in any experiment. Phenoxybenzamine in low concentrations did not affect the response, but high concentrations $(20 \mu \mathrm{g} / \mathrm{ml})$ reduced the relaxation.

Adrenaline was variable in its effect over a limited concentration range $(0 \cdot 1$ to $1 \cdot 0 \mu \mathrm{g} / \mathrm{ml})$. When its

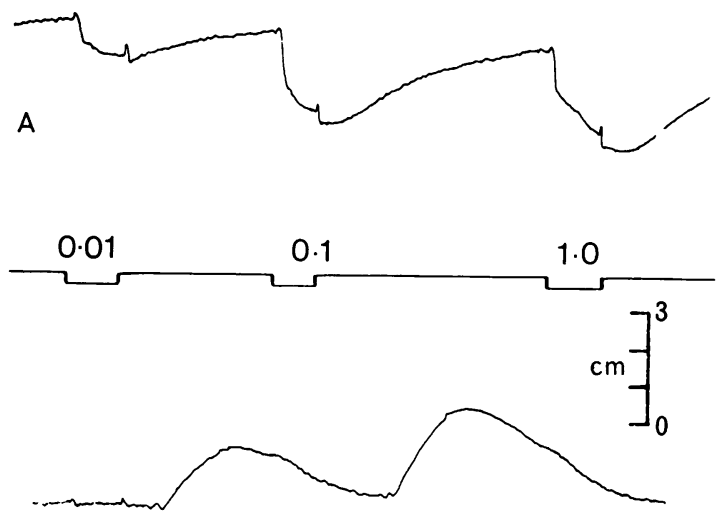

B

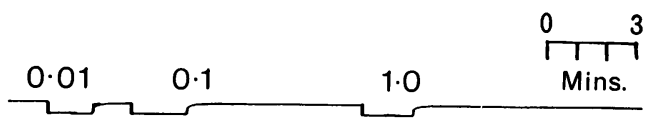

FIG. 1. The effect of adrenae on the lower part of the human internal anal sphincter $(A)$ before and $(B)$ after pronethalol. Adrenaline caused relaxation at low concentrations and this could be reversed by the addition of pronethalol $2.5 \mu \mathrm{g} / \mathrm{ml}$. The figures represent $\mu \mathrm{g} / \mathrm{ml}$ adrenaline. Strip length $17 \mathrm{~mm}$. Tension $2.5 \mathrm{~g}$. effect over a much wider concentration was investigated both parts of the sphincter usually relaxed at 0.01 to $0.1 \mu \mathrm{g} / \mathrm{ml}$ and usually contracted at concentrations over $1.0 \mu \mathrm{g} / \mathrm{ml}$. Pronethalol $(2.5 \mu \mathrm{g} / \mathrm{ml})$ antagonized the relaxation and allowed a contraction to occur at a lower concentration (Fig. 1). Similarly phenoxybenzamine $(7.5 \mu \mathrm{g} / \mathrm{ml})$ abolished the contraction and allowed an augmented relaxation.

ACETYLCHOLINE AND NICOTINE The responses of both parts of the sphincter to acetylcholine and nicotine are shown in Table II. Most of the strips from the upper part of the sphincter were sensitive to acetylcholine and contracted. The first 10 or so strips from the lower part of the sphincter did not respond at all over a wide concentration range and so many more experiments on that region were performed. A few strips contracted and a few relaxed but on the whole the responses were small. This general lack of responsiveness to acetylcholine of the lower part of the sphincter occurred in strips that were sensitive to both noradrenaline (contraction) and isoprenaline (relaxation). It is considered unlikely that this insensitivity was the result of preoperative atropine, because those strips of the upper part of the sphincter that did contract to acetylcholine gave maximal responses at low concentrations.

A more striking difference between the two parts of the sphincter was seen in the action of nicotine. Nearly all the strips from the lower part of the sphincter were insensitive to nicotine but most of those from the upper part relaxed.

The effect of nicotine upon the upper part of the sphincter was investigated further. It was found that nicotine did not cause a contraction in any experiment $(0.1$ to $100 \mu \mathrm{g} / \mathrm{ml})$ but it antagonized itself partially at $10 \mu \mathrm{g} / \mathrm{ml}$ and completely at $25 \mu \mathrm{g} / \mathrm{ml}$. Hexamethonium (50 $\mu \mathrm{g} / \mathrm{ml})$, procaine $(30 \mu \mathrm{g} / \mathrm{ml}, 30 \mathrm{~min})$ and pronethalol $(2.5 \mu \mathrm{g} / \mathrm{ml})$ also antagonized the relaxation caused by nicotine. 
TABLE II

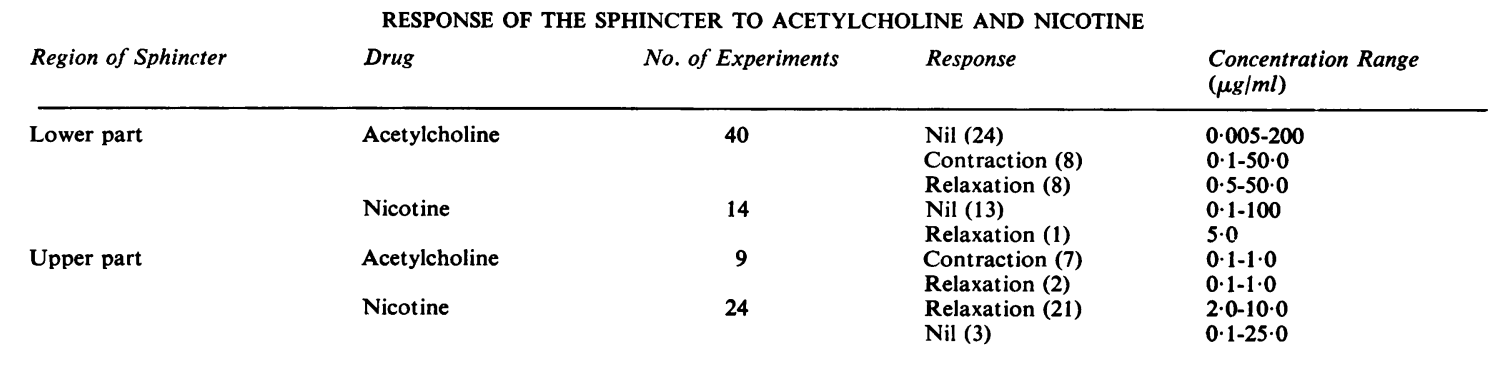

\section{DISCUSSION}

Strips from both the upper and lower parts of the internal anal sphincter relaxed in the presence of small concentrations of isoprenaline. The smallest concentration of pronethalol which antagonized this response was $2.5 \mu \mathrm{g} / \mathrm{ml}$. Bucknell and Whitney (1964), investigating the longitudinal muscle of the human colon, found that $2 \cdot 0 \mu \mathrm{g} / \mathrm{ml}$ was sufficient to antagonize the relaxation caused by isoprenaline, but not that caused by either adrenaline or noradrenaline. Although pronethalol has been reported to have local anaesthetic properties (Gill and Vaughan Williams, 1964) it can be regarded as a typical $\beta$-receptor antagonist (Levy, 1964). In our experiments the lowest concentration effective in antagonizing isoprenaline did not block the contraction responses evoked by noradrenaline and adrenaline. We think, therefore, that the effect of isoprenaline on our preparation is best explained by assuming that it acts upon $\beta$-receptors. Following $\beta$-receptor blockade isoprenaline did not appear to have any residual effect which might be attributed to other actions. Both parts of the sphincter regularly contracted in the presence of noradrenaline. The minimum concentration of phenoxybenzamine to antagonize this contraction was found to vary over a small concentration range, ie, $7 \cdot 5 \pm 2.5 \mu \mathrm{g} / \mathrm{ml}$, and following this agent noradrenaline caused the preparation to relax. This relaxation could be antagonized by pronethalol. Phenoxybenzamine is generally accepted to be an $\alpha$-receptor antagonist although it has been shown also to have other properties. The lower concentrations of phenoxybenzamine which antagonized the contraction response of noradrenaline usually did not affect the relaxations caused by isoprenaline. We think that the simplest explanation for the effects of noradrenaline is that it acts preferentially upon $\alpha$-receptors which subserve contraction. Because the response to isoprenaline could sometimes be partly reduced by high concentrations of phenoxybenz- amine, we think it likely that this agent can also affect $\beta$-receptors and this has been noticed before (Ahlquist and Levy, 1959). If these conclusions are correct then the human internal anal sphincter is composed of smooth muscle which contains both $\alpha$ and $\beta$ receptors, the former subserving contraction and the latter relaxation. If this is so then the effect of adrenaline can be explained by assuming that low concentrations preferentially affect the $\beta$-receptors and that as the concentration increases so more and more $\alpha$-receptors are stimulated.

Nicotine over a wide concentration range failed to elicit a response from most strips from the lower part of the sphincter, whereas the majority from the upper part relaxed. The effect of nicotine upon isolated intestinal preparations is well known. It can act upon cholinergic nerves in the myenteric plexus to cause contraction of the bowel wall (Ambache, 1954; Ambache and Lessin, 1955) and high concentrations will inhibit further responses. If the cholinergic nerves are blocked then nicotine frequently causes relaxation which may be the result of the stimulation of part of the inhibitory nerve network of the bowel wall (Ambache, 1951; Levy and Michel-Ber, 1953) or it may be a direct effect upon the catecholamine stores (Jarrett, 1962). Nicotine can also have a direct action upon smooth muscle. In a previous investigation it was noted that the circular muscle of the human colon regularly relaxed in the presence of nicotine and other nicotinic substances. From the results of drug antagonism we concluded that nicotine was probably acting upon adrenergic cells of the myenteric plexus (Fishlock and Parks, 1966). The site of action of nicotine upon the upper part of the sphincter cannot be determined with any certainty from our preliminary results, but the effective concentration is similar to that required in the colonic preparation, and, as hexamethonium and procaine prevent the response, it is possible that some part of the nervous element in the muscle strip is being stimulated. The fact that the lowest concentration of pronethalol to antagonize 
isoprenaline also blocked the nicotine response suggests that a catecholamine is released which activates the $\beta$-receptors. This might be an isoprenaline-like substance or it could be noradrenaline, but if so it would require to be released in close proximity to the $\beta$-receptors. This can only be a tentative conclusion. The catecholamine content of the sphincteric muscle and the effect of nicotine will have to be investigated further.

It appears that the smooth muscle cells of the anal sphincter react differently in certain respects from those of the circular muscle of the large bowel. The upper and lower parts of the sphincter show a different sensitivity to acetylcholine and some component of the upper part of the sphincter responds to nicotine. The results of this preliminary investigation underline the complexity of intestinal smooth muscle.

This work has been made possible by a grant from the Medical Research Council.

\section{REFERENCES}

Ahlquist, R. P., and Levy, B. (1959). Adrenergic receptive mechanism of canine ileum. J. Pharmacol. exp. Ther., 127, 146-149.

Ambache, N. (1951). Unmasking, after cholinergic paralysis by botulinum toxin, of a reversed action of nicotine on the mammalian intestine, revealing the probable presence of local inhibitory ganglion cells in the enteric plexuses. Brit. $J$. Pharmacol., 6, 51-67.

(1954). Autonomic ganglion stimulants. Arch. int. Pharmacodyn. 97, 427-446.

-, and Lessin, A. W. (1955). Classification of intestinomotor drugs by means of type D botulinum toxin. J. Physiol. (Lond.), $127,449-478$.

Bucknell, A., and Whitney, B. (1964). A preliminary investigation of the pharmacology of the human isolated taenia coli preparation. Brit. J. Pharmacol., 23, 164-175.

Fishlock, D. J., and Parks, A. G. (1966). The action of nicotine on the circular muscle of the human ileum and colon in vitro. Ibid, 26, 79-86.

Gill, E. W., and Vaughan Williams, E. M. (1964). Local anaesthetic activity of the $\beta$-receptor antagonist, pronethalol. Nature (Lond.), 201, 199.

Jarrett, R. J. (1962). Action of nicotine on the rabbit muscular organ (ileo-colic sphincter). Brit. J. Pharmacol., 18, 397-404.

Levy, B. (1964). Alterations of adrenergic responses by $\mathrm{N}$-isopropylmethoxamine. J. Pharmacol. exp. Ther., 146, 129-138.

Lévy, J. and Michel-Ber, E. (1953). Mécanisme de l'action de divers excito-ganglionnaires et intestin isolé de rongeurs. J. Physiol. (Paris), 45, 687-722. 